\title{
Application of Response Surface Methodology for Optimizing Process Parameters in the Production of Amylase by Aspergillus flavusNSH9 under Solid State Fermentation
}

\author{
Siti Ratina Mustafa ${ }^{1}$, Ahmad Husaini ${ }^{1 *}$, Cirilo Nolasco Hipolito ${ }^{2}$, Hasnain Hussain ${ }^{3}$, \\ Nurshikin Suhaili', Hairul Azman Roslan' ${ }^{1}$. \\ ${ }^{1}$ Universiti Malaysia Sarawak - Molecular Biology Kota Samarahan, Sarawak Malaysia; ${ }^{2}$ Universiti Malaysia \\ Sarawak - Chemical Engineering Kota Samarahan, Sarawak Malaysia; ${ }^{3}$ Molecular Biology Faculty of Resource \\ Science and Technology Universiti Malaysia Sarawak, Kota Samarahan, Malaysia.
}

\begin{abstract}
Amylase is recognized as one of the important commercial enzymes. This group of enzymes has the ability in hydrolyzing starch into smaller oligosacharides. The present work aimed to determine the optimum fermentation conditions for maximum production of crude amylase enzyme by Aspergillus flavus NSH9 employing response surface methodology (RSM).Central composite design (CCD) was applied to determine the optimal fermentation condition with respect to the four main process parameters such as temperature, initial moisture content, $\mathrm{pH}$ and the incubation period. Solid state fermentation (SSF) was performed using $5.0 \mathrm{~g}$ of sago hampas inoculated with $1 \times 10^{7}$ sporesmL $L^{-1}$ following the experimental design obtained using CCD and further optimized by RSM. The initial moisture, $p H$ and temperature showed significant effect on the amylase production $(p<0.05)$. The maximum amylase activity produced was achieved and recorded as $1.055 \pm 0.03 \mathrm{U} \mathrm{mL}^{-1}$ after four days of fermentation period with $100 \%(\mathrm{v} / \mathrm{v})$ moisture holding capacity, $\mathrm{pH} 6.5$ and temperature at $28^{\circ} \mathrm{C}$. The optimum fermentation conditions for amylase production was determined with A. flavusNSH9 on sago hampas.
\end{abstract}

Key words: Solid state fermentation, Aspergillus flavusNSH9, Sago hampas, Central Composite Design, Response Surface Methodology,

*Authors for correspondence: haahmad@ frst.unimas.my 


\section{INTRODUCTION}

Amylases are group of enzyme that act synergistically to break down the starch polysachharide (amylose and amylopectin) to glucose. There are four major groups of amylases according to van der Maarel et al, (2002) which were endoamylases, exoamylases, debranching enzyme and transferase. Amylase has been widely used in various industrial application, viz., detergent industry, alcohol production, food industry, textile industry and paper industry to name a few. Indutrially, amylase has been produced by submerged fermentation $(\mathrm{SmF})$ system. However, in recent years, researchers have devoted some effort to use solid state fermentation (SSF) for enzymes production (Hölker et al. 2004; Souza and Magalhães, 2010). SSF can be simply defined as any fermentation process allowing the growth of microorganism on solid substrate, either on inert carriers or on an insoluble substrate that acts both physical support and source of nutrients in the absence of free flowing water (Souza and Magalhães et al. 2010). Besides, SSF possess several advantages over $\mathrm{SmF}$, such as low production cost, higher product stability and lower demand of microbial contamination due to low humidity content in this system (Sun et al. 2007). Optimization processes with the one-variable-at-atime method, in which keeping other variables at fixed levels is generally time consuming and requires number of experiments to be carried out (Hajji et al. 2008;Braga et al. 2011). Response surface methodology (RSM) is a collection of statistical and mathematical techniques that able to overcome this problem. It can be used to design the experiment and evaluate the interaction between variables and response. Inaddition, RSM is useful for optimization of the desirable response (Sharma et al. 2007;Kar et al. 2008; Shaktimay et al. 2010; Vishwanatha, et al. 2010). Therefore, the aim of this study was to evaluate the optimum fermentation process conditions for crude amylase production employing RSM by A. flavus NSH9 on sago hampas.

\section{MATERIALS AND METHODS}

\section{Microorganism}

Aspergillus flavus NSH9 was grown on Malt Extract Agar (MEA) for 7 days. The inocula of spores $\left(1 \times 10^{7}\right.$ sporesmL $\left.L^{-1}\right)$ were prepared by flooding with $10 \mathrm{~mL}$ of steriled distilled water containing $0.1 \%(\mathrm{v} / \mathrm{v})$ of Tween 80 . Spores were scrapped off using sterile spatula and counted using microscopic under Neubauer Chamber (Rangarajan et al. 2010).

\section{Solid state fermentation (SSF)}

Solid state fermentation (SSF) was conducted using five grams of sago hampas inoculated with $1 \times 10^{7}$ sporesmL $^{-1}$ of 7 days old Aspergillus flavus NSH9 culture. The initial moisture content was set based on the moisture holding capacity of the substrate, the sago hampas. Moisture holding capacity of sago hampas was measured using method as described by Trautmann andKrasny (1997) and Shaktimay et al. (2010). The amount of water retained was recorded and considered as $100 \%$ moisture holding capacity. The moisture holding capacity of sago hampas was calculated using the formula (1) as follows:

Water retained $(\mathrm{mL})=$ Water added $(\mathrm{mL})-$ Water drained

The moisture holding capacity was adjusted using culture medium consisting of of the following in gram per liter: $\mathrm{K}_{2} \mathrm{HPO}_{4}, 5 ; \mathrm{MgSO}_{4}, \quad 1$; $\mathrm{CaCl}_{2} .2 \mathrm{H}_{2} \mathrm{O}, 0.05 ; \mathrm{NaCl}, 0.5 ;\left(\mathrm{NH}_{4}\right){ }_{2} \mathrm{SO}_{4}, 1.5$; peptone, 5; yeast extract, 4.The fermentation was carried out under static condition.

\section{Enzyme extraction and assay}

The crude amylase was harvested using $50 \mathrm{mM}$ sodium acetate buffer, $\mathrm{pH} 5$ with shaking for 30 minutes at agitation speed of $130 \mathrm{rpm}$. The clear supernatant was collected and used as the crude amylase enzyme preparation. The amylase assay was performed by mixing $0.5 \mathrm{~mL}$ of the crude enzyme preparation with $0.5 \mathrm{~mL}$ of $1 \%(\mathrm{w} / \mathrm{v})$ of soluble starch in $50 \mathrm{mM}$ sodium acetate buffer, $\mathrm{pH}$ 5. The reaction mixture was incubated at $37^{\circ} \mathrm{C}$ for 10 minutes. The reducing sugars released were determined by the standard dinitrosalicylic acid method (Miller, 1959).

\section{Experimental design}

The central composite design (CCD) was applied to determine the optimum physical parameter of SSF for crude amylase production with respect to four variables. The four variables were incubation period, moisture holding capacity, $\mathrm{pH}$ and temperature. Each factor in the design was studied at five different levels $(-\alpha,-1,0,+1,+\alpha)$, shown in 
Table 1. A full factorial of CCD design consists of 16 factorial points, 8 axial points and 6 replicates of the central point. The coded values for independent variable were -1 (lowest level), 0 (middle level) and +1 (highest level). The factors $(-\alpha,+\alpha)$ that ran along the axes drawn from the middle of the cube through the center of each face cube is coded as -1.682 and +1.682 , respectively. CCD was employed in order to represent response surfaces or well known as regression equation. In general, the regression equations that involve several factors are expressed as equation (2) as follows: $y=\beta_{o}+\sum_{i=\mathbf{1}}^{k} \beta_{i} x_{i}+\sum_{i=\mathbf{1}}^{k} \beta_{i i} x_{i}^{2}+\sum_{i<j=\mathbf{2}}^{k} \beta_{i j} x_{i} x_{j}+\varepsilon$ (2)

where $\mathrm{y}$ is the measured response (amylase activity); $\beta_{\mathrm{o}}, \beta_{\mathrm{i}}, \beta_{\mathrm{ii}}$ and $\beta_{\mathrm{ij}}$ are intercept term, linear, squared effect and interaction effect, respectively; $x_{i}$ is the coded for independent variables ( $i$ $=1,2,3 \ldots \mathrm{k}$ ) and $\varepsilon$ is the error (Myers et al. 2009).Design expert software (Version 7.0, StatEase, Inc) was used for regression and graphical analysis of the data obtained.

Table 1- Range of the values for central composite design (CCD)

\begin{tabular}{llllll}
\hline \multirow{2}{*}{ Variables } & \multicolumn{3}{l}{ Ranges and levels } & & \\
\cline { 2 - 6 } & $-\alpha$ & -1 & 0 & +1 & $+\alpha$ \\
\hline Incubation period (Days) & 0 & 2 & 4 & 6 & 8 \\
Moisture holding capacity (MHC) $[\%(\mathrm{v} / \mathrm{v})]$ & 25 & 40 & 55 & 70 & 85 \\
$\mathrm{pH}$ & 3.5 & 4.5 & 5.5 & 6.5 & 7.5 \\
Temperature $\left({ }^{\circ} \mathrm{C}\right)$ & 28 & 30 & 33 & 35 & 38 \\
\hline
\end{tabular}

\section{RESULTS AND DISCUSSION}

\section{Solid state fermentation and experimental design}

The optimization of solid state fermentation condition for crude amylase production by Aspergillus flavus NSH9 was successfully conducted in duplicate at laboratory experiments. Table 2 presents the experimental design of full factorial model (CCD) with the correspondent response (amylase activity). Based on the results, second order polynomial equation obtained as outlined in equation (3) as follows:

$\mathrm{y}=+0.37+0.0003 \mathrm{~A}+0.033 \mathrm{~B}+0.037 \mathrm{C}-0.045 \mathrm{D}$ $+0.040 \mathrm{AD}-0.052 \mathrm{~A}^{2}$

where $\mathrm{y}$ is the response variable which is amylase activity, A is the code for incubation period, B is for moisture holding capacity (MHC), $\mathrm{C}$ is for $\mathrm{pH}$ and $\mathrm{D}$ is for temperature.

The model F-value of 8.07 means that the model is significant and the Value of "Prob $>$ F" less than 0.05 indicated that the model term also significant. There is only a $0.01 \%$ chance that the F-value large due to noise. The lack-of-fit F-value of 2.86 implies that the lack-of-fit is not significant and only $12.42 \%$ chances that this large occur due to noise. In this study, independent variables of $\mathrm{B}, \mathrm{C}$, $\mathrm{D}, \mathrm{AD}$ and $\mathrm{A}^{2}$ were significant model term at the probability level of $95 \%$. Full model of CCD presented as 0.6779 explained that only $68 \%$ of the variability in the response. However, the predicted $R^{2}$ value $(0.2430)$ is not close to the adjusted $R^{2}$ (0.5939) which may indicate a possible problem with the model's collection due to large block effect. Adequate precision which is used to measure the signal to noise ratio was tested. A ratio greater than 4 is desirable. Ratio of 9.840 was recorded and these indicate an adequate signal. Table 3 shows the summarized analysis of variance (ANOVA) for surface quadratic model.Coefficient of variation (CV) (standard deviation/error) of $20.19 \%$ for each dependent variable showed that the statistical quality of the experimental results was acceptable prior to evaluation of the model. Prediction Error Sum of Squares (PRESS) is another statistical test that measures the adequacy of the model to predict the response (Granato et al. 2011). Small values of PRESS are desirable. In this case, the PRESS value of 0.24 was recorded. 
Table 2 - Experimental design and result of full model CCD

\begin{tabular}{|c|c|c|c|c|c|c|}
\hline \multirow{2}{*}{$\begin{array}{l}\text { Standard } \\
\text { Order }\end{array}$} & \multirow{2}{*}{$\begin{array}{l}\text { A: Incubation } \\
\text { period (days) }\end{array}$} & \multirow{2}{*}{$\begin{array}{l}\text { B: MHC } \\
(\mathrm{v} / \mathrm{v} \%)\end{array}$} & \multirow[t]{2}{*}{$\mathbf{C}: \mathbf{p H}$} & \multirow[t]{2}{*}{$\begin{array}{l}\text { D: } \\
\text { Temperature } \\
\left({ }^{\circ} \mathbf{C}\right)\end{array}$} & \multicolumn{2}{|c|}{$\begin{array}{l}\text { Amylase activity } \\
\left(\mathbf{U m L}^{-1}\right)\end{array}$} \\
\hline & & & & & Actual & Predicted \\
\hline 1 & $2(-1)$ & $40(-1)$ & $4.5(-1)$ & $30(-1)$ & 0.486 & 0.52 \\
\hline 2 & $6(+1)$ & $40(-1)$ & $4.5(-1)$ & $30(-1)$ & 0.405 & 0.39 \\
\hline 3 & $2(-1)$ & $70(+1)$ & $4.5(-1)$ & $30(-1)$ & 0.689 & 0.63 \\
\hline 4 & $6(+1)$ & $70(+1)$ & $4.5(-1)$ & $30(-1)$ & 0.302 & 0.39 \\
\hline 5 & $2(-1)$ & $40(-1)$ & $6.5(+1)$ & $30(-1)$ & 0.621 & 0.50 \\
\hline 6 & $6(+1)$ & $40(-1)$ & $6.5(+1)$ & $30(-1)$ & 0.417 & 0.52 \\
\hline 7 & $2(-1)$ & $70(+1)$ & $6.5(+1)$ & $30(-1)$ & 0.603 & 0.67 \\
\hline 8 & $6(+1)$ & $70(+1)$ & $6.5(+1)$ & $30(-1)$ & 0.547 & 0.59 \\
\hline 9 & $2(-1)$ & $40(-1)$ & $4.5(-1)$ & $35(+1)$ & 0.331 & 0.24 \\
\hline 10 & $6(+1)$ & $40(-1)$ & $4.5(-1)$ & $35(+1)$ & 0.379 & 0.34 \\
\hline 11 & $2(-1)$ & $70(+1)$ & $4.5(-1)$ & $35(+1)$ & 0.436 & 0.36 \\
\hline 12 & $6(+1)$ & $70(+1)$ & $4.5(-1)$ & $35(+1)$ & 0.284 & 0.36 \\
\hline 13 & $2(-1)$ & $40(-1)$ & $6.5(+1)$ & $35(+1)$ & 0.306 & 0.26 \\
\hline 14 & $6(+1)$ & $40(-1)$ & $6.5(+1)$ & $35(+1)$ & 0.501 & 0.52 \\
\hline 15 & $2(-1)$ & $70(+1)$ & $6.5(+1)$ & $35(+1)$ & 0.476 & 0.45 \\
\hline 16 & $6(+1)$ & $70(+1)$ & $6.5(+1)$ & $35(+1)$ & 0.606 & 0.60 \\
\hline 17 & $0(-\alpha)$ & $55(0)$ & $5.5(0)$ & $33(0)$ & 0.090 & 0.24 \\
\hline 18 & $8(+\alpha)$ & $55(0)$ & $5.5(0)$ & $33(0)$ & 0.401 & 0.26 \\
\hline 19 & $4(0)$ & $25(-\alpha)$ & $5.5(0)$ & $33(0)$ & 0.358 & 0.43 \\
\hline 20 & $4(0)$ & $85(+\alpha)$ & $5.5(0)$ & $33(0)$ & 0.687 & 0.63 \\
\hline 21 & $4(0)$ & $55(0)$ & $3.5(-\alpha)$ & $33(0)$ & 0.328 & 0.36 \\
\hline 22 & $4(0)$ & $55(0)$ & $7.5(+\alpha)$ & $33(0)$ & 0.604 & 0.58 \\
\hline 23 & $4(0)$ & $55(0)$ & $5.5(0)$ & $28(-\alpha)$ & 0.789 & 0.71 \\
\hline 24 & $4(0)$ & $55(0)$ & $5.5(0)$ & $38(+\alpha)$ & 0.358 & 0.45 \\
\hline 25 & $4(0)$ & $55(0)$ & $5.5(0)$ & $33(0)$ & 0.650 & 0.58 \\
\hline 26 & $4(0)$ & $55(0)$ & $5.5(0)$ & $33(0)$ & 0.478 & 0.58 \\
\hline 27 & $4(0)$ & $55(0)$ & $5.5(0)$ & $33(0)$ & 0.611 & 0.58 \\
\hline 28 & $4(0)$ & $55(0)$ & $5.5(0)$ & $33(0)$ & 0.598 & 0.58 \\
\hline 29 & $4(0)$ & $55(0)$ & $5.50)$ & $33(0)$ & 0.594 & 0.58 \\
\hline 30 & $4(0)$ & $55(0)$ & $5.5(0)$ & $33(0)$ & 0.527 & 0.58 \\
\hline
\end{tabular}

Table 3 -Analysis of variance for response sufrace quadratic model on the optimization of amylase production.

\begin{tabular}{|c|c|c|c|c|c|c|c|}
\hline Source & $\begin{array}{l}\text { Sum } \\
\text { squares }\end{array}$ & of & $\overline{D F}$ & $\begin{array}{l}\text { Mean } \\
\text { square }\end{array}$ & F value & $\begin{array}{l}\text { p-value } \\
(\text { Prob>F) }\end{array}$ & Remark \\
\hline Model & 0.21 & & 6 & 0.035 & 8.07 & $<0.0001$ & Significant \\
\hline A & 0.0002 & & 1 & 0.0002 & 0.058 & 0.8126 & $\begin{array}{l}\text { Not } \\
\text { significant }\end{array}$ \\
\hline B & 0.025 & & 1 & 0.025 & 5.82 & 0.0242 & Significant \\
\hline $\mathrm{C}$ & 0.033 & & 1 & 0.033 & 7.55 & 0.0115 & Significant \\
\hline D & 0.049 & & 1 & 0.049 & 11.31 & 0.0027 & Significant \\
\hline $\mathrm{AD}$ & 0.026 & & 1 & 0.026 & 5.86 & 0.0238 & Significant \\
\hline $\mathrm{A}^{2}$ & 0.078 & & 1 & 0.078 & 17.81 & 0.0003 & Significant \\
\hline Residual & 0.10 & & 23 & 0.0004 & & & \\
\hline
\end{tabular}




$\begin{array}{ccccccc}\text { Lack of fit } & 0.092 & 18 & 0.0005 & 2.86 & 0.1242 & \begin{array}{l}\text { Not } \\ \text { significant }\end{array} \\ \begin{array}{l}\text { Pure error } \\ \text { Corrected }\end{array} & 0.035 & 5 & 0.0001 & & \\ \text { Total } & 1.39 & 29 & & & \\ D \text { F, degree of freedom; } R^{2}=0.6779 ; \text { predicted } R^{2}=0.2430 ; \text { adjusted } R^{2}=0.5939 & \end{array}$

Reduced model and statistical analysis

A reduced model was proposed by eliminating the insignificant model terms. From the analysis conducted in full model, three variables which are moisture holding capacity, $\mathrm{pH}$ and temperature are significant model terms and therefore chosen as independent variables for the reduced experimental matrix. A new range and level of the variables were studied in order to further determine the maximum amylase production at different variable levels. The ranges of variable levels were set up based on the maximum production of amylase recorded in the full model. The ranges of values used were shown in Table 4 while the experimental design and amylase activity for reduced model was presented in Table 5 .

Table 4- Range of the values for reduced model

\begin{tabular}{llllll}
\hline \multirow{2}{*}{ Variables } & \multicolumn{3}{l}{ Ranges and levels } & \multicolumn{1}{c}{} \\
\cline { 2 - 6 } & $\mathbf{- \alpha}$ & $\mathbf{- 1}$ & $\mathbf{0}$ & $\mathbf{+ 1}$ & $+\boldsymbol{\alpha}$ \\
\hline Moisture holding capacity (B) [\% v/v] & 45 & 55 & 70 & 85 & 95 \\
$\mathrm{pH}(\mathrm{C})$ & 3.82 & 4.5 & 5.5 & 6.5 & 7.18 \\
Temperature (D) $\left.\left[{ }^{\circ} \mathrm{C}\right)\right]$ & 26 & 28 & 31 & 33 & 35 \\
\hline
\end{tabular}

Based on the results in Table 5, first order equation was obtained as shown in equation (4) as follows:

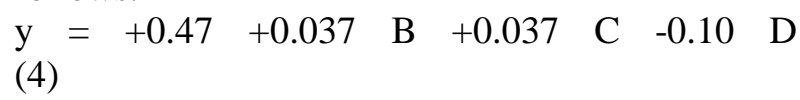

where $\mathrm{y}$ is the response variable (amylase activity), $\mathrm{B}$ is the code moisture holding capacity, $\mathrm{C}$ is for initial $\mathrm{pH}$ and $\mathrm{D}$ is for temperature.

The model F-value of 17.19 implies that the model is significant. The lack-of-fit F-value of 2.38 implies that the lack-of-fit is not significant and $17.42 \%$ chances that this large occur due to noise. In this study, independent variables of $\mathrm{B}, \mathrm{C}$ and $\mathrm{D}$ were found to be the significant model terms at the probability level of $95 \%$. The ANOVA for response surface linear model was summarized in Table 6. The regression coefficient equation obtained showed that the values of coefficient determination $\left(\mathrm{R}^{2}\right)$ was 0.7632 , indicating that $76.32 \%$ of the variability in the response could be explained by the model. Moreover, the predicted
$\mathrm{R}^{2}$ value of 0.6048 was at reasonable agreement with the adjusted $R^{2}$ value of 0.7188 . An adequate precision of 13.345 for amylase activity was recorded. A greater value of F-value in reduced model $(=17.19)$ indicates that reduced model was highly significant model compared to full model (F-value = 8.07). According to Shi et al. (2009), the model is a good prediction of the experimental results if the calculated $F$ value is several times greater than the tabulated $\mathrm{F}$ value. This was proven when the F-value $(=17.19)$ shows five times greater values than the tabulated $\mathrm{F}$-value $[\mathrm{F}(3,16)$ $=3.24)$ ] at 0.05 level. Therefore, the independent variables of $\mathrm{B}, \mathrm{C}$ and $\mathrm{D}$ studied were significant model terms at the probability level of $95 \%$ for amylase production. The $\mathrm{CV}$ in the reduced model showed improved value of $12.67 \%$ thus indicating better statistical quality of the experimental results. Small PRESS values (0.093) was recorded as an indicator that the reduced model is adequate to predict the response.

Table 5 - Experimental design and result of reduced model CCD

\begin{tabular}{llllll}
\hline $\begin{array}{l}\text { Standard } \\
\text { Order }\end{array}$ & $\begin{array}{l}\text { B: } \\
\text { Mositure } \\
\text { holding } \\
\text { capacity }(\mathrm{v} /\end{array}$ & $\mathbf{C}: \mathbf{p H}$ & $\begin{array}{l}\text { D: } \\
\text { Temperature } \\
\left({ }^{\circ} \mathrm{C}\right)\end{array}$ & & $\begin{array}{l}\text { Amylase activity } \\
\left(\mathrm{UmL}^{-1}\right)\end{array}$ \\
\cline { 5 - 7 } & & & Actual & Predicted \\
\hline
\end{tabular}




\begin{tabular}{llllll}
\hline \multicolumn{7}{c}{ v \%) } & & & & \\
\hline 1 & $55(-1)$ & $4.5(-1)$ & $28(-1)$ & 0.795 & 0.73 \\
2 & $85(+1)$ & $4.5(-1)$ & $28(-1)$ & 0.914 & 0.85 \\
3 & $55(-1)$ & $6.5(+1)$ & $28(-1)$ & 0.819 & 0.83 \\
4 & $85(+1)$ & $6.5(+1)$ & $28(-1)$ & 0.935 & 0.93 \\
5 & $55(-1)$ & $4.5(-1)$ & $33(+1)$ & 0.523 & 0.44 \\
6 & $85(+1)$ & $4.5(-1)$ & $33(+1)$ & 0.556 & 0.54 \\
7 & $55(-1)$ & $6.5(+1)$ & $33(+1)$ & 0.445 & 0.54 \\
8 & $85(+1)$ & $6.5(+1)$ & $33(+1)$ & 0.55 & 0.64 \\
9 & $45(-\alpha)$ & $5.5(0)$ & $31(0)$ & 0.666 & 0.60 \\
10 & $95(+\alpha)$ & $5.5(0)$ & $31(0)$ & 0.841 & 0.77 \\
11 & $70(0)$ & $3.82(-\alpha)$ & $31(0)$ & 0.446 & 0.60 \\
12 & $70(0)$ & $7.18(+\alpha)$ & $31(0)$ & 0.863 & 0.77 \\
13 & $70(0)$ & $5.5(0)$ & $26(-\alpha)$ & 0.893 & 0.93 \\
14 & $70(0)$ & $5.5(0)$ & $35(+\alpha)$ & 0.541 & 0.44 \\
15 & $70(0)$ & $5.5(0)$ & $31(0)$ & 0.767 & 0.68 \\
16 & $70(0)$ & $5.5(0)$ & $31(0)$ & 0.674 & 0.68 \\
17 & $65(0)$ & $5.5(0)$ & $31(0)$ & 0.605 & 0.68 \\
18 & $65(0)$ & $5.5(0)$ & $31(0)$ & 0.617 & 0.68 \\
19 & $65(0)$ & $5.5(0)$ & $31(0)$ & 0.626 & 0.68 \\
20 & $65(0)$ & $5.5(0)$ & $31(0)$ & 0.608 & 0.68 \\
\hline
\end{tabular}

Table 6 -Analysis of variance for response sufrace linear model

\begin{tabular}{llllll}
\hline Source & $\begin{array}{l}\text { Sum of } \\
\text { squares }\end{array}$ & DF & $\begin{array}{l}\text { Mean } \\
\text { square }\end{array}$ & F value & $\begin{array}{l}\text { p-value } \\
\text { (Prob>F) }\end{array}$ \\
\hline Model & 0.18 & 3 & 0.060 & 17.19 & $<0.0001$ \\
Lack of fit & 0.047 & 11 & 0.0003 & 2.38 & 0.1742 \\
Pure error & 0.0008 & 5 & 0.0001 & & \\
Corrected & 0.24 & 19 & & & \\
Total & & & & & \\
ffreedom; $R^{2}=0.7632 ;$ predicted $R^{2}=0.6048 ;$ adjusted $R^{2}=0.7188$ &
\end{tabular}

$D F$, degree of freedom; $R^{2}=0.7632 ;$ predicted $R^{2}=0.6048 ;$ adjusted $R^{2}=0.7188$

declined with the increase in the incubation period

Response surface plotting

The response surface three dimensional diagrams were employed in order to further study the interactive effects of factors on the production of amylase enzyme. Figure 1(a) shows the response surface curves of the relationship between incubation period and temperature while the moisture holding capacity and $\mathrm{pH}$ were kept at $70 \%$ and pH6.5, respectively. The figure demonstrated that amylase enzyme activity was and also the temperature. Figure 1(b) represented the relationship between moisture holding capacity and $\mathrm{pH}$ while keeping the temperature at $28^{\circ} \mathrm{C}$ in the reduced model. The diagram generated from the reduced model experiment showed the linear pattern. Thus, these indicated less complex interaction between the variables and the response. The amylase enzyme activity was increased with the increase of $\mathrm{pH}$ and moisture holding capacity. 


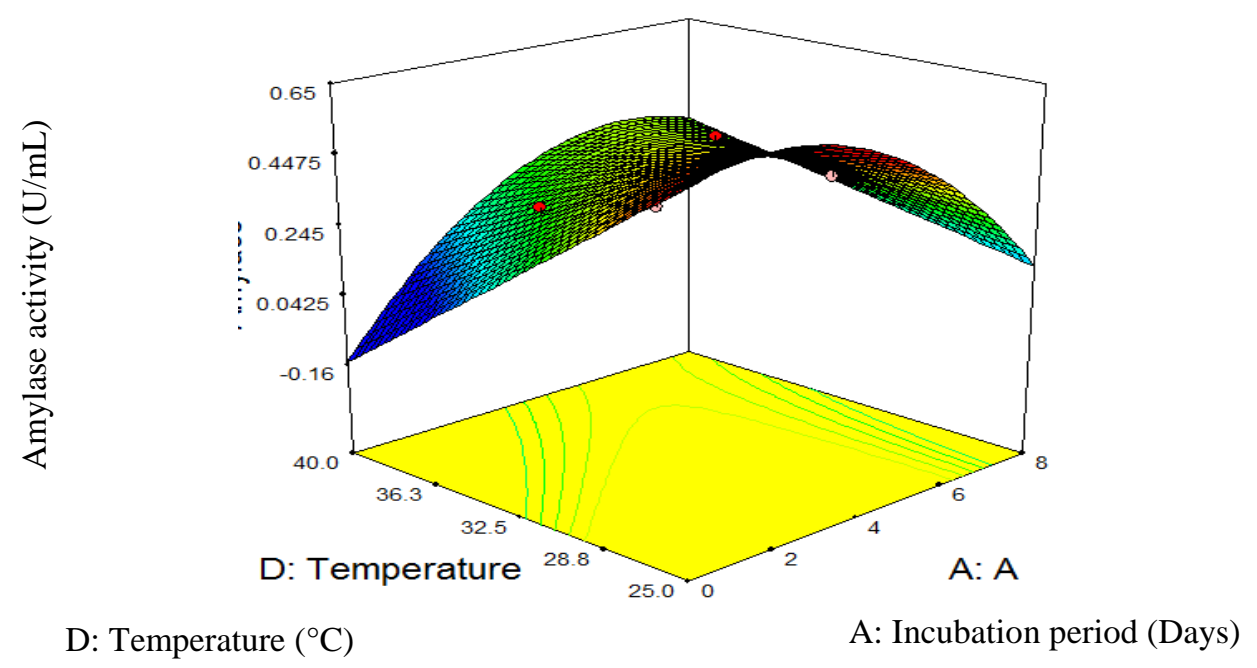

(a)

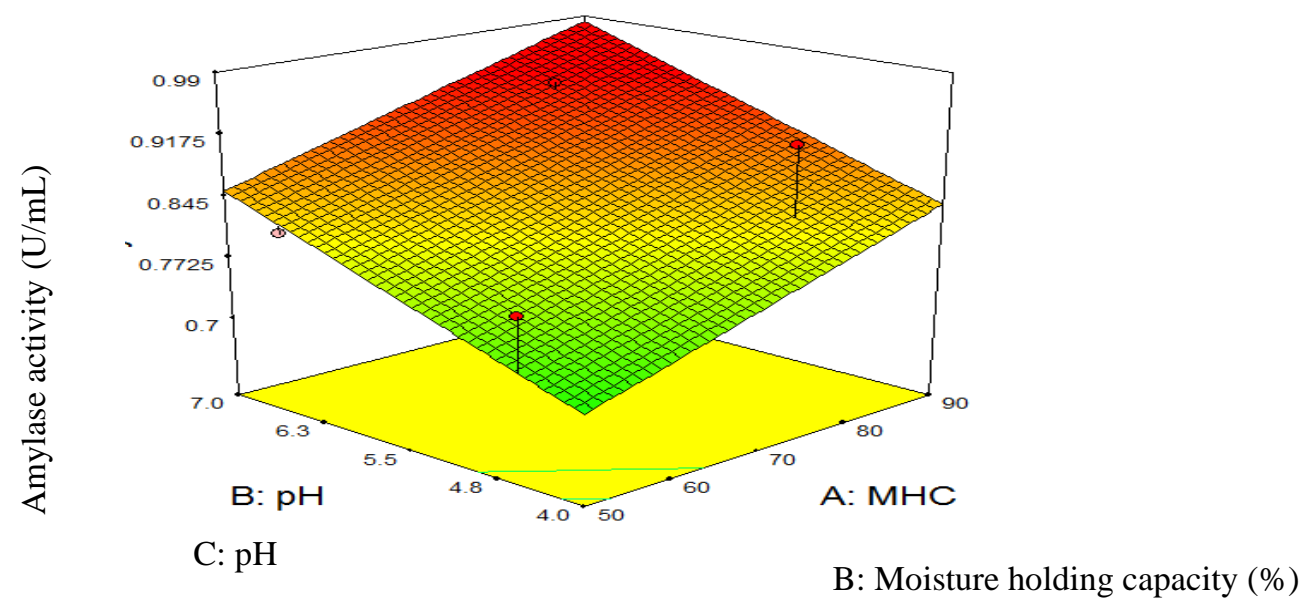

(b)

Figure 1- Response surface curve indicating the interaction between the variables on crude amylase production (a) temperature and incubation period (b) $\mathrm{pH}$ and moisture holding capacity. Blue, green and red colors indicate the amount amylase activity at low, intermediate and at high amount respectively.

The moisture level is main factor in SSF which often determines the success of the system. This is supported by Mitchell et al. (2000) and Neifar et al. (2011), whereby they reported that in SSF system the microorganism obtained water from the moisture held within the substrate particles which is essential for fungal growth, metabolism and the production of secondary metabolites. Moisture holding capacity has been reported as one of the important factors that influence the growth of the organism and also the enzyme production in SSF (Baysal et al. 2003; Shaktimay et al. 2010). Sun et al. (2009) further reported that moisture content was a factor that caused the swelling of the substrates thus gives effects on the gas exchange in the fermentation system. At lower level of moisture content, the degree of swelling was low and caused higher water tension thus reduces the solubility of nutrients in the system. On the other hand, higher moisture content level brings the changes on substrate particles which decreases the porosity hence promotes the development of stickiness and reduces the gas exchange. The presence of gas exchange was crucial in facilitating the utilization of substrate by the microorganism (Mahanta et al. 2008; Murdula et 
al. 2011). In general, the moisture holding capacity varies between $60 \%-80 \%$ that is required for an efficient SSF system (Grover et al. 2013). However, throughout this study, maximum amylase production was recorded at $100 \%$ of moisture holding capacity.

In this study, the moisture holding capacity, $\mathrm{pH}$ and temperature had the most effects on amylase production. The moisture level is the main factor in SSF which often determines the success of the system. According to Baysal et al. (2003), the initial moisture content of the substrate influences the growth of the organisms and enzyme production in SSF. While $\mathrm{pH}$ is also an important factor that affect the morphological changes and enzyme secretion by the microorganism since they are sensitive to the concentration of hydrogen ions presents in the medium (Sivaramakrishnan et al. 2006; Bhimba et al. 2011). Generally, the optimum $\mathrm{pH}$ required for the growth of fungi is slightly acidic ( $\mathrm{pH} 4.0-6.5$ ). In this study, $\mathrm{pH} 6.5$ was recorded as the best $\mathrm{pH}$ for maximum crude amylase production. Balkan et al. (2005) reported that temperature plays an important role in the development of the fermentation process since it influences the protein denaturation, enzyme inhibition and cell growth. The optimum temperature for enzyme production by most microorganisms was recorded within the range of $25-37^{\circ} \mathrm{C}$ (Ramachandran et al. 2004; Sun et al. 2009; Abdel-Banat et al. 2010). Maximum crude amylase production by Aspergillus flavus NSH9 was determined at $28^{\circ} \mathrm{C}$. The production of amylase enzyme was declined as the incubation temperature increases. This clearly indicates that the amylase enzyme production in solid state fermentation is significantly affected by temperature.

Optimization and verification of theoretical results Optimization and verification experiments were done in order to find out the optimum level of process parameters by maximizing the response. The criteria were set as presented in Table 7. The confirmatory experiments were carried out to further support the optimized data as given by the statistical modelling according to the solutions determined by the reduced model with higher desirability (Table 8).

Table 7 -Optimization criteria used in this study

\begin{tabular}{llll}
\hline \multirow{2}{*}{ Parameter } & Limit & & Criterion \\
\cline { 2 - 3 } & Lower & Upper & Maximize \\
\hline Moisture holding capacity $[\%(\mathrm{v} / \mathrm{v})]$ & 80 & 100 & Maximize \\
$\mathrm{pH}$ & 5.5 & 7 & Target \\
Temperature $\left({ }^{\circ} \mathrm{C}\right)$ & 28 & & Maximize \\
Enzyme activity $\left(\mathrm{UmL}^{-1}\right)$ & 0.030 & 0.690 &
\end{tabular}

The optimization and verification were carried out in triplicate for a period of four days of incubation.

Error $=\underset{100 \%}{(5)} \frac{\text { Actual value }- \text { Predicted value }}{(5}$

Actual value predicted and the actual values was calculated based on the following equation (5):

Table 8 -Verification of theoretical results of optimized combination of fermentation parameters for amylase production

\begin{tabular}{llllllll}
\hline Solution & $\begin{array}{l}\text { Moisture } \\
\text { holding } \\
\text { capacity } \\
{[\%(\mathbf{v} / \mathbf{v})]}\end{array}$ & $\mathbf{p H}$ & $\begin{array}{l}\text { Temperature } \\
\left({ }^{\circ} \mathbf{C}\right)\end{array}$ & $\begin{array}{l}\text { Predicted } \\
\text { value, } \\
\text { amylase } \\
\text { activity } \\
\left(\mathbf{U m L}^{-1}\right)\end{array}$ & $\begin{array}{l}\text { Actual } \\
\text { value, } \\
\text { amylase } \\
\text { activity } \\
\left(\mathbf{U ~ m L}^{-1}\right)\end{array}$ & Desirability & $\begin{array}{l}\text { Error } \\
(\%)\end{array}$ \\
\hline 1 & 100 & 7 & 28 & 1.050 & 1.013 & 1 & -3.5 \\
$\mathbf{2}$ & $\mathbf{1 0 0}$ & $\mathbf{6 . 5}$ & $\mathbf{2 8}$ & $\mathbf{1 . 0 2 2}$ & $\mathbf{1 . 0 5 5}$ & $\mathbf{0 . 9 9 8}$ & $\mathbf{3 . 2}$ \\
\hline
\end{tabular}




\begin{tabular}{llllllll}
\hline 3 & 90 & 7 & 28 & 1.013 & 1.025 & 0.997 & 1.2 \\
4 & 90 & 6.5 & 28 & 0.956 & 1.037 & 0.985 & 8.4 \\
5 & 85 & 6.5 & 28 & 0.967 & 1.030 & 0.989 & 6.5 \\
6 & 80 & 6.5 & 28 & 0.950 & 0.983 & 0.989 & 3.5 \\
\hline
\end{tabular}

Based on the results in Table 8, the optimized fermentation parameters condition yielded the amylase production closer to the predicted values except for Solution 4 and 5. Even though, the two solutions of 4 and 5 shows error more that $5 \%$, but they produced higher activity than predicted thus indicating that RSM is a suitable model for optimization. Therefore, from six solutions performed, Solution 2 was chosen as the optimum condition as a result of higher amylase production compared to the other solutions. Furthermore, these results corroborated with the validity of the response model and the effectiveness of the reduced model for the optimization process in the production of amylase by Aspergillus flavus NSH9 on sago hampas.

\section{CONCLUSION}

Optimum solid state fermentation condition for amylase production by Aspergillus flavus NSH9 on sago hampas was successfully achieved by using response surface methodology (RSM). The RSM is proven to be a beneficial statistical tool for designing, performing and analyzing the experiments. Besides that, this tool enables the elimination of insignificant variables thus reduces the time consumed and size of experiments run. The optimum fermentation process parameters obtained were at $100 \%(\mathrm{v} / \mathrm{v})$ moisture holding capacity, $\mathrm{pH} 6.5$, temperature at $28^{\circ} \mathrm{C}$ with incubation period of four days which gave $1.055 \pm$ $0.03 \mathrm{UmL}^{-1} 1$ of amylase activity.

\section{ACKNOWLEDGEMENTS}

The research project was funded by TunOpeng Sago Chair, University Malaysia Sarawak research grant with reference no: ORC/07/2011(03).

\section{REFERENCES}

Abdel-Banat BM, Hoshida H, AnoA, Nonklang S, Akada, R. High-temperature fermentation: how can processes for ethanol production at high temperatures become superior to the traditional process using mesophilic yeast? Appl. Microbiol. Biotechnol.2010; 85(4): 861-867.

Balkan B,ErtanF.Production and properties of $\alpha$ amylase from Penicillium chrysogenum and its application in starch analysis.Prep. Biochem.Biotechnol.2005; 35:169-178.

Baysal, Z, Uyar, F. and Aytekin, C. Solid state fermentation for production of $\alpha$-amylase by a thermotolorant Bacillus subtilis from hot spring water.Process Biochem.2003; 38:1665-1668.

Bhimba BV, Yeswanth S, Naveena BE. Characterization of extracellular amylase enzyme produced by Aspergillus flavus MV5 isolated from mangrove sediment. Indian J Nat Prod Resour. 2011; 2(2): 170-173.

Braga FR, Araújo JV, Soares FEF, Araujo JM, Geniêr HLA, Silva AR, Ferreira SR. Optimizing protease production from an isolate of the nematophagous fungus Duddingtoniaflagrans using response surface methodology and its larvicidal activity on horse cyathostomins. J Helminthol.2011; 85(02): 164-170.

Granato D, Favalli G, Maria V, Calado DA. Experimental design and application of response surface methodology for proccess modelling and optimization: A review. Food Res Int. 2011.doi:10.1016/j.foodres.2010.12.008.

Grover A, Maninder A, Sarao, LK.Production of fungal amylase and cellulase enzymes via solid state fermentation using Aspergillus oryzae and Trichoderma reesei.IJOART. 2013; 2(8): 108-124.

Hajji M, Rebai A, Gharsallah N, Nasri M.Optimization of alkaline protease production by Aspergillus clavatus ES1 in Mirabilis jalapa tuber powder using statistical experimental design. Appl. Microbiol. Biotechnol.2008; 79: 915-923.

Hölker U, Höfer M,Lenz J. Biotechnological advantages of laboratory-scale solid state fermentation with fungi. Appl. Microbiol. Biotechnol.2004;64: 175-186.

Kar S, Ray RC, Mohapatra UB. Alpha-amylase production by Streptomyces erumpens MTCC 7317 in solid state fermentation using response surface methodology (RSM).Pol J Microbiol.2008; 57(4): 289-96.

Mahanta N, Gupta A,Khare SK. Production of protease and lipase by solvent tolerant Pseudomonas aerugina PseA in solid state fermentation using Jatropha curcas seed cake as substrate. Bioresour.Technol.2008; 99: 1729-1735. 
Miller GL. Use of dinitrosalicylic acid reagent for determination of reducing sugar. Anal.Chem.1959;31: 426-428.

Mrudula S,Anitharaj R. Pectinase production in solid state fermentation by Aspergillus niger using orange peel as substrate. GJBBR, 2011; 6(2): $64-71$.

Myers RH, Montgomery DC, Anderson-Cook CM. Response Surface Methodology: Process and product optimization using designed experiments (3rd ed.). New York: John Wiley and Sons; 2009.

NeifarM, Kamoun A, Jaouani A, Ellouze-Ghorbel R, Ellouze-Chaabouni S. Application of asymetrical and hoke designs for optimization of laccase production by the white-rot fungus Fomesfomentarius in solidstate fermentation. Enzyme Research, 2011.Article ID 368525, 12 pages, doi:10.4061/2011/368525

Ramachandran S, Patel AK, Nampoothiri KM, Francis F, Nagy V, Szakacs G, Pandey A. Coconut oil cakeA potential raw material for the production of $\alpha$ amylase.Bioresour.Technol. 2004; 93: 29-36.

Rangarajan V, Rajasekharan M, Ravichandran R, Sriganesh K,Vaitheeswaran V. Pectinase production from orange peel extract and dried orange peel solid as substrates using Aspergillus niger.Int. J. Biotechnol. Biochem.2010;6(3): 445-453.

Shaktimay K, Datta TK, Ray RC. Optimization of thermostable $\alpha$-amylase production by Streptomyces erumpens MTCC 7317 in solid-state fermentation using cassava fibrous residue.Braz. Arch. Biol. Technol.2010; 53(2): 301-309.

Sharma P, Goel R, Capalash N. Bacterial laccases. World J. Microbiol.Biotechnol.2007; 23: 823-832.

Shi Y, Xu X, Zhu Y. Optimization of Verticilliumlecanii spore production in solid-state fermentation on sugarcane bagasse.Appl. Microbiol. Biotechnol.2009; 82(5): 921-927.
Sivaramakrishnan S, Gangadharan D, Madhavan K, Soccol CR, Pandey A. $\alpha$-amylases from microbial sources - an overview on recent developments. Food Tech Biotechnol.2006; 44(2): 173-184.

Souza PM, Magalhães PO. Application of microbial $\alpha$ amylase in industry - a review.Braz. $J$. Microbiol.2010; 41: 850-861.

Sun H, Ge X, Wang L, Zhao P, Peng M. Microbial production of raw starch digesting enzymes.Afr. J. Biotechnol.2009; 8(9): 1734-1739.

Sun H, Ge X, Zhang W. Production of novel raw starch digesting glucoamylase by Penicillium sp. X-1 under solid state fermentation and its use in direct hydrolysis of starch. World J. Microbiol.Biotechnol.2007; 23: 603-613.

Trautmann NM,Krasny ME. 1997. Composting in the classroom. http://www. cfe.cornell. edu/compost/schools.html

van der Maarel MJEC, van der Veen B, Uitdehaag JCM, Leemhuis H, Dijkhuizen L. Properties and applications of starch-converting enzymes of the alpha-amylase family. J Biotechnol.2002; 94(2): 137 55.

Vishwanatha KS, Rao AA, Singh SA. Acid protease production by solid-state fermentation using Aspergillus oryzae MTCC 5341: optimization of process parameters. J. Ind. Microbiol. Biotechnol. 2010; 37(2): 129-138.

Received: October 17, 2015; Accepted: February 15, 2016. 